\title{
Determination of hydrogen cyanide concentration in mainstream smoke of tobacco products by polarography
}

\author{
Shabnam Mahernia, Arash Amanlou, Gita kiaee and Massoud Amanlou*
}

\begin{abstract}
Background: There has been a worldwide concern for the health risks of cigarette smoking and hydrogen cyanide ( $\mathrm{HCN}$ ) considered as one of the hazardous tobacco compounds which is needed to be determined in order to reduce the dose related to smoke disease risk.

In this study, we prepare the experimental procedure to entrap the HCN from mainstream smoke of different brands of Tehran cigarette, through simulating human inhalation and determine its concentration applying polarography.

Results: The HCN level of the 50 commonly consumed tobacco products (47 cigarettes and 3 cigars) obtained from local store is ranged between $17.56 \pm 1.02$ and $1553.98 \pm 0.56 \mu \mathrm{g}$ per stick, this acquired amount is more than FDA approval ( $10 \mu \mathrm{g}$ per stick), so the harmful effects of smoking is indicative.

Conclusions: The comparative study of the results shows that the price and the weight of each product do not indicate HCN level. As can be seen, $R^{2}$ value which is a statistical measure of how close the data are to the fitted regression line is low $\left(R^{2}<0.2\right)$. So it should not be deceived by names such as ultra light or infinite gravity to suck, because this names or the price haven't effect on the amount of HCN and its destructive effects.
\end{abstract}

Keywords: Tobacco products, Cigarette, Hydrogen cyanide, Polarography

\section{Background}

Smoking is the major risk factor of mortality in the world according to the statistical information; the cigarette consumption during one century has increased over 100 times, which increases the concern over the safety of tobacco products $[1,2]$.

Tobacco smoke contains more than 5000 chemical compounds which 150 of these substances have been proved to be toxicants [3, 4]. Hydrogen cyanide is one of the tobaccos smoke poisonous substances which are formed from the combustion of the protein and nitrate compounds existed in tobacco at high temperatures in the oxygen deficient condition $[5,6]$ which it's chronic and low exposure causes neurological, respiratory, cardiovascular and thyroid effect [7-9].

\footnotetext{
* Correspondence: amanlou@tums.ac.ir

Department of Medicinal Chemistry, Faculty of Pharmacy and Pharmaceutical Sciences Research Center, Tehran University of Medical Sciences, Tehran, Iran
}

The tobacco smoke pathway includes the part directly entered the mouth called mainstream and the part diffused in the surrounding, called side stream, which hazardous for nonsmoker. The level of HCN in mainstream smoke is ranged from 10 to $400 \mu \mathrm{g}$ per cigarette (US Brands) which 0.6 to $27 \%$ of these amounts exist in side stream smoke [10]. In the previous study the level of $\mathrm{HCN}$ in the non-filtered cigarette was between 400 to $500 \mu \mathrm{g}$ per stick [11] and in another study the amount of $\mathrm{HCN}$ in the mainstream smoke of cigar, non-filtered cigarette and filtered cigarette was 1035, 59 and $448 \mu \mathrm{g}$ per $1 \mathrm{~g}$ of tobacco, respectively and in small cigars it was between 510 to $780 \mu \mathrm{g}$ per $1 \mathrm{~g}$ of tobacco [12].

There are different reported methods determine $\mathrm{HCN}$ in different samples including voltammetry [13], fluorometry $[14,15]$ gas chromatography [16], LC-MS-MS [17], HPLC-MS [18], potentiometry [19], spectrophotometry [20] and colorimetry [21]. Among them, polarography the subclass of voltammetry is the most precise and 
Table 1 Hydrogen cyanide concentration and price of different brands of cigars

\begin{tabular}{|c|c|c|c|c|c|c|}
\hline No. & Brand & $\begin{array}{l}\text { Cyanide concentration } \\
(\mu \mathrm{g} / \mathrm{cig} .)\end{array}$ & $\begin{array}{l}\text { Number of cig. per } \\
\text { pocket }\end{array}$ & $\begin{array}{l}\text { The price of each } \\
\text { pocket(\$) }\end{array}$ & $\begin{array}{l}\text { Weight of each cig. } \\
(\mathrm{mg})\end{array}$ & $\begin{array}{l}\text { The price of each } \\
\text { cig. (\$) }\end{array}$ \\
\hline 1 & Bahman & 368.067 & 20 & 0.58 & 828.4 & 0.02 \\
\hline 2 & Bahman & 574.358 & 20 & 0.50 & 587.7 & 0.02 \\
\hline 3 & Bahman & 57.655 & 20 & 0.50 & 547.8 & 0.02 \\
\hline 4 & Bistoon & 227.491 & 20 & 0.41 & 943.7 & 0.02 \\
\hline 5 & CAFÉ CRÈME & 791.067 & 10 & 2.08 & 921.6 & 0.20 \\
\hline 6 & CAFÉ CRÈME (AROME) & 1464.900 & 10 & 2.08 & 1053.2 & 0.20 \\
\hline 7 & CAFÉ CRÈME (BLUE) & 406.722 & 10 & 1.83 & 746.6 & 0.18 \\
\hline 8 & CAMEL Lights & 184.825 & 20 & 1.62 & 810.1 & 0.08 \\
\hline 9 & Cima & 237.400 & 20 & 0.66 & 863.9 & 0.03 \\
\hline 10 & Cima classic & 120.720 & 20 & 0.60 & 687.6 & 0.03 \\
\hline 11 & Dunhill & 300.717 & 20 & 2.25 & 781.9 & 0.11 \\
\hline 12 & Eclipse & 740.235 & 20 & 12.50 & 1243.6 & 0.62 \\
\hline 13 & ESSE Lights & 131.012 & 20 & 0.80 & 515.2 & 0.04 \\
\hline 14 & ESSE Special Gold & 29.622 & 20 & 0.66 & 530.2 & 0.03 \\
\hline 15 & Jewels sweet & 1553.584 & 20 & 1.62 & 6165.5 & 0.08 \\
\hline 16 & Kent & 297.693 & 20 & 1.33 & 793.7 & 0.06 \\
\hline 17 & Kent & 190.745 & 20 & 1.25 & 436.9 & 0.06 \\
\hline 18 & Kent (Blue7) & 345.930 & 20 & 1.25 & 915.8 & 0.06 \\
\hline 19 & Kent (White1) & 188.220 & 20 & 1.25 & 776.2 & 0.06 \\
\hline 20 & King Edward & 598.518 & 5 & 1.41 & 3384.2 & 0.28 \\
\hline 21 & Magna & 232.889 & 20 & 0.79 & 822.4 & 0.03 \\
\hline 22 & Magna & 145.228 & 20 & 1.79 & 763.8 & 0.08 \\
\hline 23 & Magna & 212.310 & 20 & 0.79 & 813.3 & 0.04 \\
\hline 24 & Marlboro Gold (Germany) & 165.871 & 20 & 3.75 & 800.3 & 0.18 \\
\hline 25 & Marlboro (Extra) (USA) & 164.309 & 20 & 4.16 & 900.2 & 0.20 \\
\hline 26 & Marlboro (Switzerland) & 17.561 & 20 & 2.66 & 849.1 & 0.13 \\
\hline 27 & Marlboro (Switzerland) & 47.892 & 20 & 2.91 & 969.7 & 0.14 \\
\hline 28 & Marlboro Lights & 267.804 & 20 & 2.50 & 858.9 & 0.12 \\
\hline 29 & Marlboro Lights (USA) & 42.916 & 20 & 2.91 & 776.4 & 0.14 \\
\hline 30 & $\begin{array}{l}\text { Marlboro Lights } \\
\text { (Switzerland) }\end{array}$ & 74.536 & 20 & 2.91 & 786.5 & 0.14 \\
\hline 31 & $\begin{array}{l}\text { Marlboro Lights } \\
\text { (Switzerland) }\end{array}$ & 69.344 & 20 & 1.83 & 816.5 & 0.09 \\
\hline 32 & $\begin{array}{l}\text { Marlboro Ultra Lights } \\
\text { (Switzerland) }\end{array}$ & 127.336 & 20 & 2.66 & 835.1 & 0.13 \\
\hline 33 & Montana & 332.493 & 20 & 0.50 & 855.6 & 0.02 \\
\hline 34 & Pall Mall & 161.785 & 20 & 0.83 & 905.1 & 0.04 \\
\hline 35 & Pall Mall (Blue) & 86.956 & 20 & 0.83 & 881.3 & 0.04 \\
\hline 36 & PHILLIES BLUNT & 203.178 & 5 & 1.62 & 6974.5 & 0.32 \\
\hline 37 & Pine (Blue) & 238.561 & 20 & 0.66 & 860.2 & 0.03 \\
\hline 38 & Pine (supper slims) & 94.813 & 20 & 0.45 & 547.2 & 0.02 \\
\hline 39 & Winston & 43.187 & 20 & 1.25 & 785.9 & 0.06 \\
\hline 40 & Winston & 214.325 & 20 & 1.50 & 816.7 & 0.07 \\
\hline 41 & Winston & 106.176 & 20 & 1.50 & 831.0 & 0.07 \\
\hline
\end{tabular}


Table 1 Hydrogen cyanide concentration and price of different brands of cigars (Continued)

\begin{tabular}{|c|c|c|c|c|c|c|}
\hline 42 & Winston Blue (Europe) & 99.244 & 20 & 1.83 & 537.3 & 0.09 \\
\hline 43 & Winston Lights & 66.326 & 20 & 2.50 & 943.1 & 0.12 \\
\hline 44 & Winston Lights (Imported) & 209.294 & 20 & 4.58 & 814.0 & 0.22 \\
\hline 45 & Winston Lights (USA) & 102.132 & 20 & 2.08 & 808.7 & 0.10 \\
\hline 46 & Winston Ultra Lights (USA) & 42.634 & 20 & 2.25 & 794.1 & 0.11 \\
\hline 47 & Winston Ultra Lights (USA) & 25.554 & 20 & 2.25 & 818.4 & 0.11 \\
\hline 48 & $\begin{array}{l}\text { Winston Ultra Lights } \\
\text { (Switzerland) }\end{array}$ & 254.322 & 20 & 2.25 & 812.0 & 0.67 \\
\hline 49 & Zest Lights & 150.623 & 20 & 0.66 & 829.9 & 0.03 \\
\hline 50 & Zika & 288.120 & 20 & 2.91 & 924.0 & 0.14 \\
\hline
\end{tabular}

inexpensive method based on the oxidation and reduction mechanism [22].

The aim of this study is focused on the determination of the $\mathrm{HCN}$ in mainstream smock of different brands of cigarette consumed in Tehran using polarography method.

\section{Materials and methods Collection of samples}

A total of 50 types of different brands of the most consumed or available cigarettes (47) and cigars (3) were collected from local stores at September 2012. The $20 \%$ of the samples were from Winston company, $18 \%$ from Marlboro, $6 \%$ from Magna, $8 \%$ from KENT and $8 \%$ from local or officially imported companies and the rest, $40 \%$ are from a different companies (as shown in Table 1).

\section{Reagents and chemicals}

All chemicals used were of analytical reagent grade from Merck (Germany). Buffer solutions were prepared by dissolving boric acid $(0.2 \mathrm{M})$ and potassium hydroxide $(0.17 \mathrm{M})$ in $1000 \mathrm{ml}$ ultrapure water and adjusting the solution to $\mathrm{pH}$ 10.2. Cyanide standard solution (1 g/L) was prepared by dissolving $0.2503 \mathrm{~g} \mathrm{KCN}$ in $100 \mathrm{ml}$ $\mathrm{KOH} 0.01 \mathrm{M}$ in ultrapure water.

\section{Apparatus}

Analysis was conducted by the Metrohm Polarography device 797 VA Computrace, three electrode systems consisting of a dropping mercury electrode (DME) as the working electrode, an $\mathrm{Ag} / \mathrm{AgCl}$ reference electrode and platinum counter electrode. The device outfitted in the following conditions: stirrer speed $2000 \mathrm{rpm}$, mode DP, purge time $300 \mathrm{~s}$, equilibration time $5 \mathrm{~s}$, pulse amplitude $50 \mathrm{mV}$, start potential $0 \mathrm{~V}$, end potential $-500 \mathrm{mV}$, voltage step $8 \mathrm{mV}$, voltage step time $0.8 \mathrm{~s}$, sweep rate $10 \mathrm{mV} / \mathrm{s}$, peak potential $\mathrm{CN}-240 \mathrm{mV}$. All instrumental settings were those recommended in the manufacturer's manual book and the instrumental conditions with the method of AB110-Det of cyanide [23]. All potentials quoted were measured against an $\mathrm{Ag} / \mathrm{AgCl}$ reference electrode and the polarographic cell volume was $20 \mathrm{ml}$.

\section{Method of analysis}

The $\mathrm{HCN}$ in each cigarette and cigar mainstream smoke were collected using mainstream apparatus (Fig. 1) $[24,25]$. The cigarette was applied to the entrance station and suction force obtained by the vacuum pump simulate the human inhalation and extract the tobacco smoke, the flow of smoke were passed through the glass tube filled with $100 \mathrm{ml} \mathrm{NaOH}(0.1 \mathrm{M})$ solution to entrap $\mathrm{HCN}$ as $\mathrm{CN}^{-}$ion.

Subsequently, the mixture of above mentioned solution contain cigarette smoke $(10 \mathrm{ml})$ and buffer solution $(10 \mathrm{ml})$ was added to the polarographic vessel and deoxygenated for $10 \mathrm{~min}$ with high-purity nitrogen and achieved the peak of $\mathrm{CN}^{-}$in the range of $-0.5-0 \mathrm{~V}$. To determine the $\mathrm{CN}^{-}$ concentration by standard addition method, $50 \mu \mathrm{l}$ cyanide standard solution was added (two times) and the polarogram was obtained (Fig. 2).

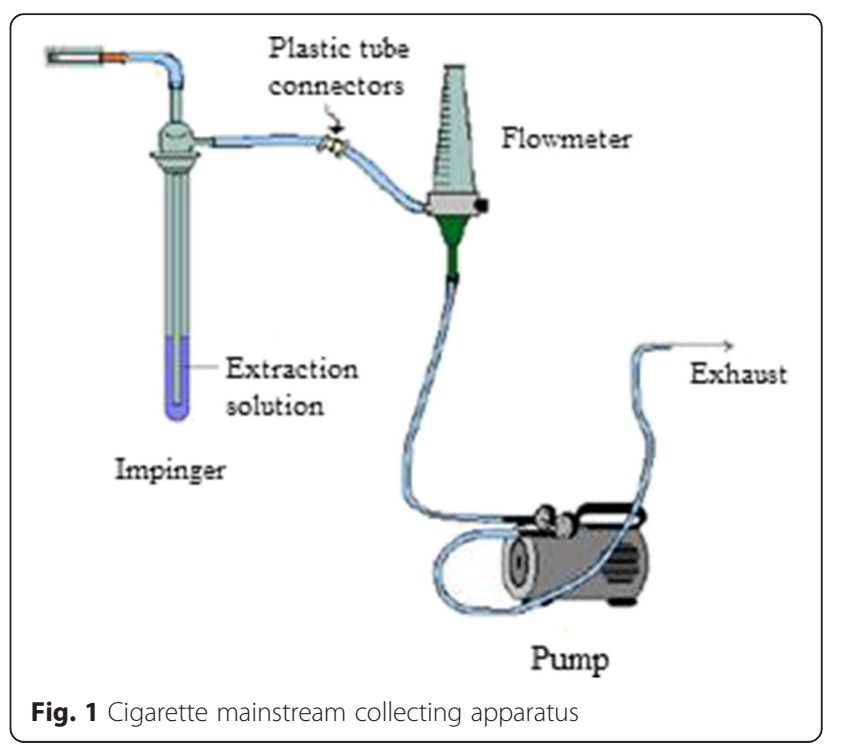



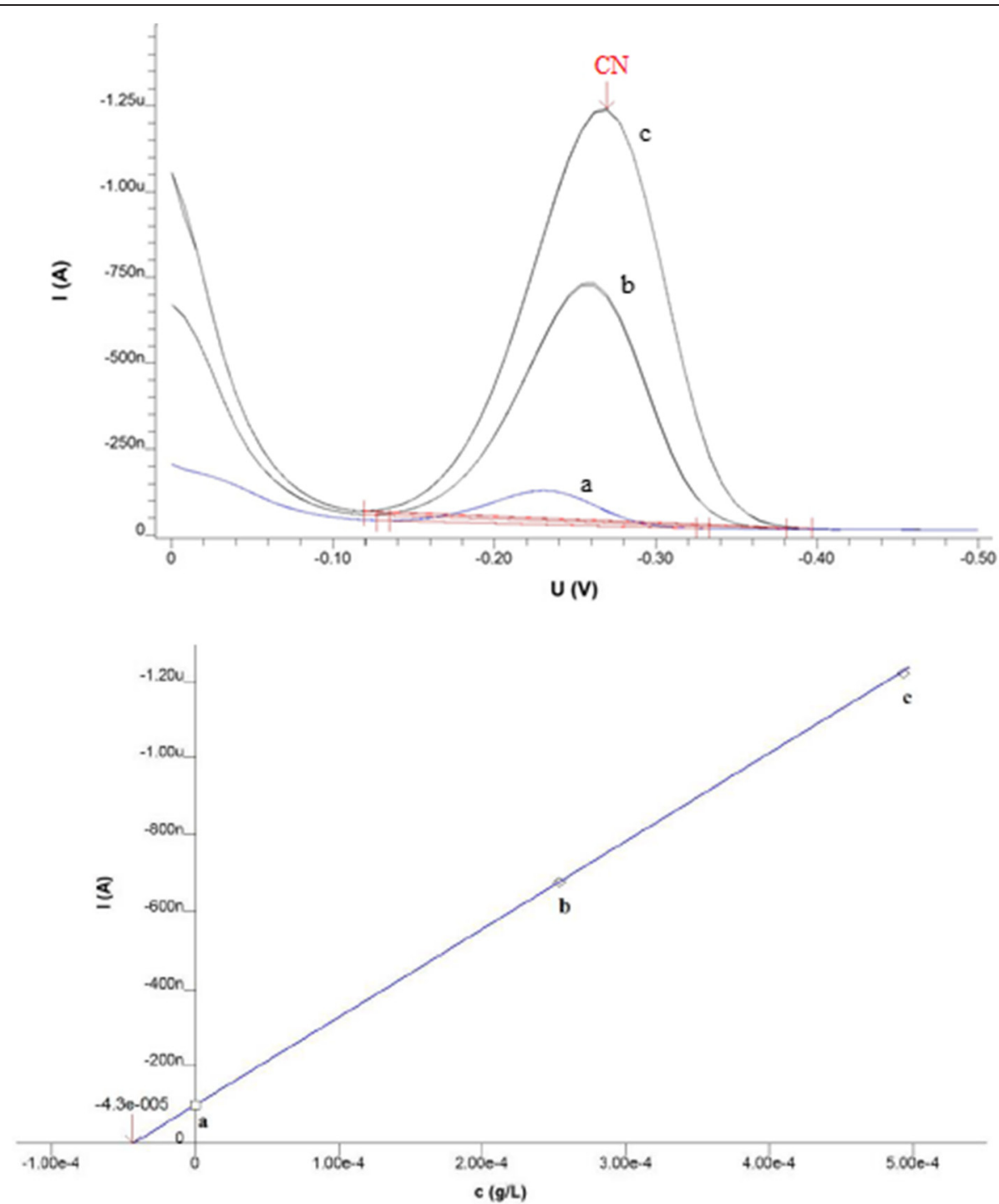

Fig. 2 The differential pulse polarogram of cyanide ion in cigarette smoke sample. a the peak of sample solution $\mathbf{b}$ the peak of first dilution of standard addition $\mathbf{c}$ the peak of second dilution of standard addition

\section{Statistical analysis}

All statistical analyses were performed using the statistical software for social sciences (SPSS Inc. Chicago, IL, Version 21). Statistical analyses of each sample were characterized by mean \pm standard deviation. The mean levels of cyanide were compared across categories of price, and weight of each cigarette or cigars. The significance level was defined at 0.05 for the regression equations.

\section{Result and discussion}

The result of mainstream smoke $\mathrm{HCN}$ determination by polarography (Table 1) showed that among 50 samples the average amount of $\mathrm{HCN}$ was $184.825 \mu \mathrm{g}$ per stick which the highest level of $\mathrm{HCN}$ pertain to Jewel sweet cigar, $1553.98 \pm 0.56 \mu \mathrm{g}$ per cigar, and the lowest was
Swiss Marlboro with $17.56 \pm 1.02 \mu$ g per cigarette. Moreover, the average amount of $\mathrm{HCN}$ in cigarettes and cigar were $218 \mu \mathrm{g}$ and $785.09 \mu \mathrm{g}$, respectively, In addition the average weight of cigarette and cigar samples was $800 \mathrm{mg}$ and $5500 \mathrm{mg}$, respectively, and the average weight of whole samples was $1084.24 \mathrm{mg}$.

The changes in the $\mathrm{HCN}$ levels are dependent on the preparation procedure of tobacco, which lead to the diverse amount of proteins and nitrate compounds of cigarette which render the conversion of $\mathrm{HCN}$ level emission. In addition it may be possible to assess the quality of cigarette especially ultralight by determining the amount of $\mathrm{HCN}$ as it is increased in the unfeigned products.

Furthermore, based on our study there is no connection between price, weight and appearance of cigarette, 


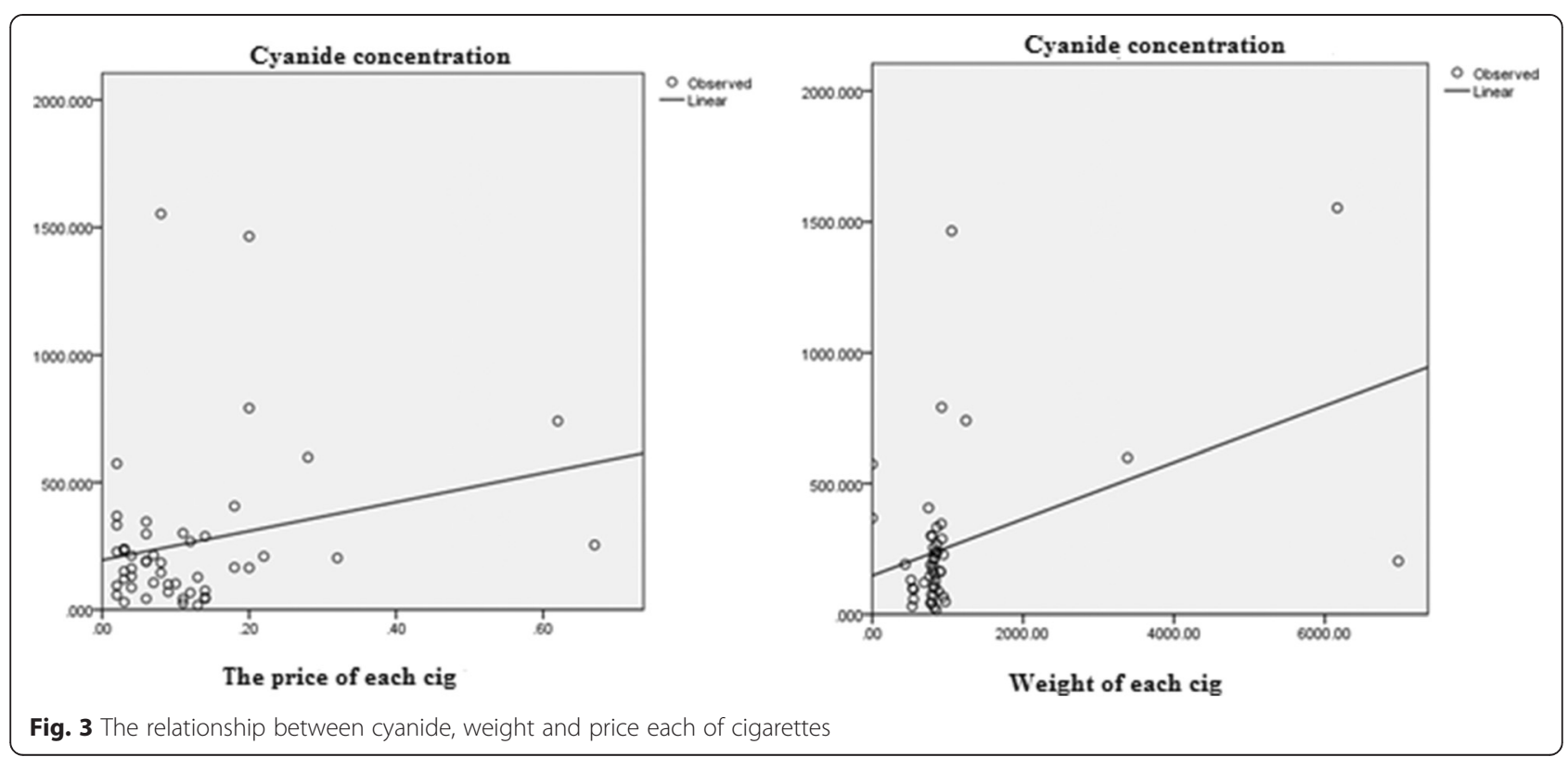

cigar and HCN level. For instance, Jewels sweet and PHILLIES BLUNT cigars have the same price, but different level of HCN doesn't necessarily cause the higher $\mathrm{HCN}$ level emission. The regression method was applied for the development of the mentioned model. Validation of the method was conducted by analyzing the different set of independent data from the same source. As can be seen the $R^{2}$ which is a statistical measure of how close the data are to the fitted regression line is low (0.20) (Fig. 3). So it means the model is useless for prediction based on cigar and cigarette weight and its price.

In addition, previous studies demonstrated that even exposure to lower concentrations of cyanide may result in a range of non-specific features include headache, dizziness, throat discomfort, chest tightness and eye irritation which these symptoms would grow by more

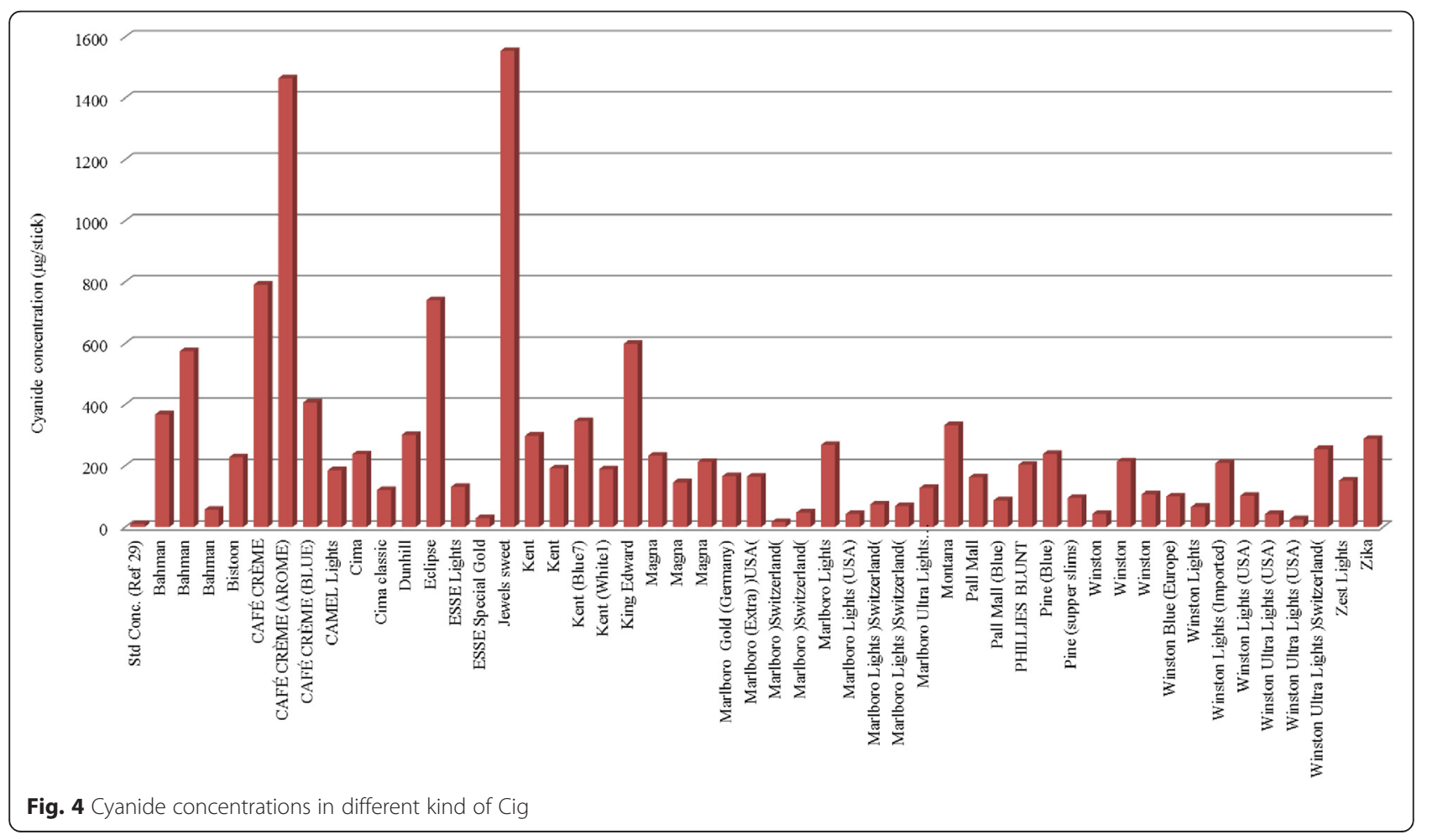


substantial exposure [26-28]. Moreover the results of our study indicate that cyanide concentration of all samples, even light cigarette is above established levels for chronic toxic doses [9] (Fig. 4).

\section{Conclusions}

In this study, $\mathrm{HCN}$ of the toxic components of the tobacco smoke was determined by polarographic method. The results shows that the ranges of $\mathrm{HCN}$ level of 50 samples were varied between $17.56 \pm 1.02-1553.98 \pm$ $0.56 \mu \mathrm{g}$ per stick. This acquired amount is more than FDA approval (10 $\mu \mathrm{g}$ per stick).

\section{Competing interests}

The authors declare that they have no competing interests.

\section{Authors' contributions}

All authors contributed to the concept and design, providing and analysis of data, drafting, revising and final approval. MA is responsible for the study registration. AA is responsible for collection. SM is responsible for experiments performing, assembly of data, data analysis, interpretation, SM and GK are responsible for writing the manuscript and correcting. All authors read and approved the final manuscript.

\section{Acknowledgment}

We gratefully acknowledge the financial support from Tehran University of Medical Sciences.

Received: 10 February 2014 Accepted: 11 July 2015

Published online: 29 July 2015

\section{References}

1. General S. Reducing the health consequences of smoking. 25 years of progress. US Department of Health and Human Services. 1989.

2. Shafey O, Eriksen M, Ross H, Mackay J. The Tobacco Atlas. 3rd ed. Atlanta, GA: Am Cancer Soc; 2009.

3. Fowles J, Dybing E. Application of toxicological risk assessment principles to the chemical constituents of cigarette smoke. Tob Control. 2003;12:424-30.

4. Green CR, Schumacher JN, Llovd RA, Rodgman A. Comparisons of the composition of tobacco smoke and the smokes from various tobacco substitutes. Beit Tabakforsch Intl. 2007;22:257-89.

5. Norman V, Ihrig A, Larson T, Moss B. The effect of some nitrogenous blend components on NO/NOx and HCN levels in mainstream and sidestream smoke. Beitr Tabakforsch. 1983;12:55-62.

6. Baker R. Smoke Chemistry, Tobacco production. Blackwell Publishing Ltd: Chemistry and technology; 1999. p. 398-439.

7. Blanc P, Hogan M, Mallin K, Hryhorczuk D, Hess S, Bernard B. Cyanide intoxication among silver-reclaiming workers. JAMA. 1985;253:367-71.

8. Chandra H, Gupta B, Bhargava S, Clerk S, Mahendra P. Chronic cyanide exposure biochemical and industrial hygiene study. J Anal Toxicol. 1980;4:161-5.

9. El Ghawabi SH, Gaafar MA, El-Saharti AA, Ahmed SH, Malash KK, Fares R. Chronic cyanide exposure. a clinical, radioisotope, and laboratory study. Br J Ind Med. 1975;32:215-9.

10. Fiksel J, Slimak MW, Little AD. An Exposure and Risk Assessment for Cyanide. Monitoring and Data Support Division, Office of Water Regulations and Standards. US: Environmental Protection Agency; 1981.

11. Hoffmann D, Hoffmann I. Risks of tobacco smoke exposure are similar for all sources of tobacco smoke, and the magnitude of the risks experienced by cigar smokers is proportionate to the nature and intensity of their exposure. Chem and Toxicol. 1998;55.

12. Adams Pl. Combustion temperatures in cigars and cigarettes, A comparative study. Tobacco Sci. 1968:12:144-50

13. Safavi A, Maleki N, Shahbaazi H. Indirect determination of cyanide ion and hydrogen cyanide by adsorptive stripping voltammetry at a mercury electrode. Anal Chim Acta. 2004;503:213-21.
14. Lundquist P, Rosling H, Sörbo B, Tibbling L. Cyanide concentrations in blood after cigarette smoking, as determined by a sensitive fluorimetric method. Clin Chem. 1987;33:1228-30.

15. Chen D, Castro M, Valcarcel M. Flow-through sensor for the fluorimetric determination of cyanide. Talanta. 1990;37:1049-55.

16. Brunnemann KD, Yu L, Hoffmann D. Chemical studies on tobacco smoke. XLIX. Gas chromatographic determination of hydrogen cyanide and cyanogen in tobacco smoke. J Anal Toxicol. 1977;1:38-42.

17. Lacroix C, Saussereau E, Boulanger F, Goulle J. Online liquid chromatography-tandem mass spectrometry cyanide determination in blood. J Anal Toxicol. 2011;35:143-7.

18. Tracqui A, Raul J, Geraut A, Berthelon L, Ludes B. Determination of blood cyanide by HPLC-MS. J Anal Toxicol. 2002;26:144-8.

19. Bark L, Higson H. A review of the methods available for the detection and determination of small amounts of cyanide. Analyst. 1963;88:751-60.

20. Surleva AR, Visualizing DG, Hazard S. A simple spectrophotometric determination of hydrogen cyanide in cigarette smoke and filters. J Chem Edu. 2013;90:1654-7.

21. Fowler E, Steele TW. The determination of anionic surface-active agents in dilute aqueous solution. Johannesburg: National Institute for Metallurgy; 1968

22. Surleva A. Recent achievements in toxic cyanide monitoring: review. Revue electronique internationale pour la science et la technologie. Numéro. 2009. p. 3.

23. Polarographic determination of free cyanide No, 110/2 e. In: Metrohm application bulletin

24. Determination of Hydrogen Cyanide in Sidestream Tobacco Smoke. Health Canada. 1999.

25. Diekmann J, Biefel C, Rustemeier K. Analysis of cigarette mainstream smoke for 1,1-dimethylhydrazine and vinyl acetate by gas chromatography-mass spectrometry. J Chromatogr Sci. 2002;40:509-14.

26. National Poisons Information Service (NPIS) Hydrogen cyanide. Toxbase ${ }^{\bullet} 2000$.

27. Lam KK, Lau FL. An incident of hydrogen cyanide poisning. Am J Emerg Med. 2000;18:172-5.

28. Agency for Toxic Substances and Disease Registry (ATSDR). Draft Toxicological Profile for Cyanide. Atlanta. US: US Department of Health and Human Services; 2004.

\section{Submit your next manuscript to BioMed Central and take full advantage of:}

- Convenient online submission

- Thorough peer review

- No space constraints or color figure charges

- Immediate publication on acceptance

- Inclusion in PubMed, CAS, Scopus and Google Scholar

- Research which is freely available for redistribution 